\title{
Guidelines for the management of surgical departments in non-uniform hospitals during the COVID-19 pandemic
}

Expert team Directed by National Consultant in the field of Ceneral Surgery Prof. dr hab. n. med. Grzegorza Wallnera:

Authors' Contribution: A-Study Design B-Data Collection C-Statistical Analysis D-Data Interpretation E-Manuscript Preparation F-Literature Search G-Funds Collection

\author{
Kryspin Mitura ${ }^{1 \mathrm{EF}}$, Piotr Myśliwiec ${ }^{2 \mathrm{AEF}}$, Wojciech Rogula ${ }^{3 \mathrm{EF}}$, Michał Solecki ${ }^{4 \mathrm{EF}}$, Jarosław Piotr Furtak ${ }^{5 \mathrm{EF}}$, \\ Michał Kazanowski ${ }^{6 \mathrm{EF}}$, Stanisław Kłęk ${ }^{\mathrm{7EF}}$, Michał Nowakowski ${ }^{\mathrm{EEF}}$, Michał Pędziwiatr ${ }^{8 \mathrm{EF}}$, \\ Marek Zawadzki ${ }^{9 \mathrm{EF}}$, Grzegorz Wallner ${ }^{4 \mathrm{EF}}$, Jacek Sobocki ${ }^{1{ }^{10 F}}$ \\ 'Department of Medical and Health Sciences, Siedlce University of Natural Sciences and Humanities, Poland; \\ Head: prof. Kryspin Mitura MD PhD \\ ${ }^{2}$ 1st Clinical Department of Ceneral and Endocrine Surgery, Medical University of Bialystok, Poland; Head: prof. Jacek Dadan MD PhD \\ ${ }^{3}$ Clinical Department of Pediatric Surgery, University Children's Hospital in Cracow, Jagiellonian University, Cracow, Poland; \\ Head: Wojciech Górecki MD PhD \\ ${ }^{4}$ 2nd Clinic of General and Gastroenterological Surgery and Gastroenterological Tumours of the Medical University of Lublin, \\ Independent Public Teaching Hospital No. 1 in Lublin, Poland; Head: prof. Grzegorz Wallner MD PhD \\ ${ }^{5}$ Department of Surgery, Independent Public Health Care Institution in Puławy - Special Hospital for Infectious Diseases, Poland; \\ Head: Jarosław Piotr Furtak MD PhD \\ ${ }^{6}$ Castrointestinal Cancer Surgery Department, Lower Silesian Oncology Center, Wroclaw, Poland; Head: prof. Marek Bębenek MD PhD \\ 7 Department of Ceneral Surgery and Gastrointestinal Insufficiency Treatment, Stanley Dudrick Multi-Specialist Hospital, Skawina, \\ Poland; Head: prof. Stanisław Kłę MD PhD \\ ${ }^{8}$ 2nd Department of General Surgery, Faculty of Medicine, Jagiellonian University Medical College, \\ University Hospital in Cracow - Special COVID-19Hospital, Poland; Head: prof. Andrzej Matyja MD PhD \\ ${ }^{9}$ Provincial Specialist Hospital in Wroclaw, Department of Oncological Surgery, Faculty of Health Sciences, \\ Medical University of Silesian Piasts in Wroclaw, Poland; Head: prof. Wojciech Witkiewicz MD PhD \\ ${ }^{10} \mathrm{Ceneral}$ Surgery and Clinical Nutrition Clinic, Centre of Postgraduate Medical Education, Warsaw, Poland; \\ Head: prof. Jacek Sobocki MD PhD
}

Article history: Received: 11.04.2020 Accepted:14.04.2020 Published: 15.04 .2020

ABSTRACT: In the last several weeks we have been witnessing the exponentially progressing pandemic SARS-CoV-2 coronavirus. As the number of people infected with SARS-CoV2 escalates, the problem of surgical management of patients requiring urgent surgery is increasing. Patients infected with SARS-CoV2 virus but with negative test results will appear in general hospitals and may pose a risk to other patients and hospital staff. Health care workers constitutes nearly $17 \%$ of infected population in Poland, therefore early identification of infected people becomes a priority to protect human resources and to ensure continuity of the access to a surgical care. Both surgical operations, and endoscopic procedures are considered as interventions with an increased risk of infection. Therefore, determining the algorithm becomes crucial for qualifying patients for surgical treatment, but also to stratify the risk of personnel being infected during surgery and to adequately protect staff. Each hospital should be logistically prepared for the need to perform urgent surgery on a patient with suspected or confirmed infection, including personal protective equipment. Limited availability of the equipment, working under pressure and staff shortages in addition to a highly contagious pathogen necessitate a pragmatic management of human resources in health care. Instant synchronized action is needed, and clear uniform guidelines are essential for the healthcare system to provide citizens with the necessary surgical care while protecting both patients, and staff. This document presents current recommendations regarding surgery during the COVID-19 pandemic in Poland.

KEYWORDS: $\quad$ COVID-19, epidemic, FFP3 masks, guidelines, hospital, personal protective equipment, recommendations, SARS-CoV-2 pandemic, surgery, surgical care, virus

\section{ABBREVIATIONS}

AEC/SAS - Spanish Association of Surgeons ANSI - American National Standards Institute CRP - C-reactive protein

EAES - European Association for Endoscopic Surgery

EN - enteral nutrition

FSMP - Foods for Special Medical Purposes

ICU - Intensive care unit

NSAIDs - non-steroidal anti-inflammatory drugs

ONS - oral nutritional supplements

PN - parenteral nutrition

PPE - personal protective equipment
RNA - ribonucleic acids

RT-PCR - reverse transcription polymerase chain reaction SAGES - Society of American Gastrointestinal and Endoscopic Surgeons

SARS-CoV-2 - severe acute respiratory syndrome coronavirus 2 TK - computed tomography

USG - ultrasonography

\section{INTRODUCTION}

We have been participating in an exponentially progressive coronavirus SARS-CoV-2 pandemic for several weeks now [1]. 
Twenty-one specialist hospitals were established in Poland to treat the COVID-19 disease, pursuant to the decision of the Minister of Health of March 13th, 2020 [2]. As the number of people infected with SARS-CoV2 escalates, the problem of surgical management of patients requiring urgent surgery is increasing [3]. Patients infected with SARS-CoV2 with negative test results will inevitably appear in hospitals other than special COVID-19 hospitals, possibly posing a risk to other patients and hospital personnel. In a situation where healthcare workers constitute nearly $17 \%$ of the infected population in Poland, early identification of infected people becomes a priority to protect human resources and to ensure continuity of access to surgical care [4]. Operating theaters are areas of high risk for the transmission of respiratory infections, taking into account the involvement of multiple workers in the same room when performing elevated-risk activities. Therefore, determining the algorithm for qualifying patients for surgical treatment becomes crucial, so does stratifying the risk of personnel becoming infected during surgery and adequately protecting the staff. Any hospital may find itself in a situation where immediate surgery is required for a patient with a high risk of SARS-CoV-2 infection. Because of that, every hospital should be prepared for this eventuality organizationally and logistically, including the protection with personal protective equipment. Finally, it may be necessary to set up additional special COVID-19 infection hospitals, which will necessitate the adaptation of surgical departments and operating theaters.

Limited availability of the equipment, working under pressure and staff shortages, in addition to a highly contagious pathogen, necessitate a pragmatic management of human resources in health care [5]. Immediate, coordinated action and clear, uniform guidelines are needed to enable the health system to provide citizens with the necessary surgical care while protecting patients and personnel.

From the point of view of SARS-CoV-2 infection and the development of COVID-19, and the separation into standard ("non-uniform") and special ("uniform" or COVID-19 dedicated) hospitals, there are four groups of surgical patients distinguished, according to the division shown in Tab. I.

\section{ALCORITHM FOR MANAGEMENT OF PATIENTS REQUIRING SURGERY}

The qualification for surgery during pandemic is influenced by the patient's clinical condition and the hospital's logistical and organizational capabilities. Depending on the local intensity of the pandemic, conditions will change dynamically. The Spanish Association of Surgeons (AEC/SAS) has prepared guidelines that have been accepted by SAGES (Society of American Gastrointestinal and Endoscopic Surgeons) and EAES (European Association for Endoscopic Surgery), which regulate local surgical activity depending on the severity and activity of the pandemic (Tab. II.) [6].

The decision on the qualification of a patient to the appropriate risk group (elective, expedited, urgent or emergency procedure) should be decided by a multidisciplinary team, which would be responsible for making decisions and setting the priority of treatment for each patient.

If the patient is qualified for surgery during the COVID-19 pandemic, it is necessary to do the following, in respective settings:
Tab. I. Patient groups according to the risk of infecting others.

\begin{tabular}{|c|c|c|c|}
\hline $\begin{array}{l}\text { RISK GROUP FOR THE } \\
\text { INFECTION OF OTHERS }\end{array}$ & $\begin{array}{l}\text { COVID-19 } \\
\text { SYMPTOMS }\end{array}$ & SARS-COV-2 TEST & $\begin{array}{l}\text { TREATMENT IN THE } \\
\text { HOSPITAL }\end{array}$ \\
\hline low & none & negative & standard \\
\hline moderate & none & pending & standard \\
\hline high & $\begin{array}{l}\text { none } \\
\text { present } \\
\text { present }\end{array}$ & $\begin{array}{l}\text { positive } \\
\text { negative } \\
\text { pending }\end{array}$ & $\begin{array}{l}\text { special COVID-19 } \\
\text { dedicated unit }\end{array}$ \\
\hline very high & present & positive & $\begin{array}{l}\text { special COVID-19 } \\
\text { dedicated unit }\end{array}$ \\
\hline
\end{tabular}

Scheduled, elective procedure: it is advisable to postpone all elective procedures, in case when postponement of such will not result in any harm to patients' health. The decision to postpone the surgery is made by the surgeon responsible for treating the patient. This will significantly reduce patient migration in hospitals and reduce the spread of disease between patients and medical personnel. Additionally, at the moment of highest demand, it will reduce the number of occupied hospital beds and the consumption of personal protective equipment, and secure larger human resources ready for work [7].

Treatments for oncological indications should be approved by an oncological medical case specialist panel discussion. In the absence of alternative treatment (radiotherapy, chemotherapy) and threatening progression of the tumor, it seems justified to qualify the patient for surgery. In cases of e.g. rectal cancer, a long irradiation can be performed or, with the $5 \times 5$ Gy regimen, it is possible to extend the interval from 6-9 weeks to 8-12 weeks after the scheduled treatment [8]. Due to the significant risk of virus spread in aerosols during endoscopic procedures, screening and diagnostic tests should be limited to what is strictly necessary. Small procedures like elective polypectomies should be postponed until the pandemic is over [9]. However, patients with higher-grade tumors, threatening to develop e.g. progressive obstruction, should be qualified for primary surgical treatment.

All patients admitted to the department in urgent mode should have a thorough epidemiological interview and an assessment of the most common symptoms (including temperature measurement). Suspected patients should be redirected to specialist COVID-19 infection hospitals for further treatment. As a part of the initial diagnostics, in order to be qualified for admission, they should have a CT scan of the thorax without contrast or, if no CT is available, an X-ray scan of the thorax in A-P projection [10]. The diagnostic value of 3-quadrant lung ultrasound is also high, although the prevalence of this technique in Poland is still low. According to the analysis of the population of Chinese patients, patients with confirmed COVID-19 had usually normal leukocyte count or insignificant leukopenia, decreased platelet count, with elevated CRP level and non-specific D-dimer increase [11].

Before each surgical procedure, the possibility of SARSCoV-2 infection and its consequences should be discussed with the patient. This information should be included in the informed consent form.

Before surgery, it is necessary to perform a test for SARSCoV-2 if the patient's condition allows to wait for the test result. However, it should be noted that this time must be as short as possible. 
Tab. II. The phases of the epidemic

\begin{tabular}{|c|c|c|c|c|}
\hline EPIDEMIC PHASES & $\begin{array}{l}\text { PERCENTACE OF PATIENTS INFECTED } \\
\text { IN HOSPITAL AND/OR ICU }\end{array}$ & $\begin{array}{l}\text { SELECTION OF PATIENTS } \\
\text { IN HOSPITAL EMERGENCY } \\
\text { DEPARTMENT }\end{array}$ & HOSPITAL RESOURCES & SURCICAL ACTIVITIES \\
\hline PHASE 1 low risk & $<5 \%$ & not necessary & no effect & no effect \\
\hline PHASE 2 moderate risk & $5-25 \%$ & $\begin{array}{l}\text { 1. patients with respiratory } \\
\text { symptoms, } \\
\text { 2. others. }\end{array}$ & $\begin{array}{l}\text { no effect, but the hospital is ready } \\
\text { for a pandemic }\end{array}$ & $\begin{array}{l}\text { 1. emergency procedures, } \\
\text { 2. oncological procedures with } \\
\text { suspected growth of infections } \\
\text {-as in phase } 3 \text {. }\end{array}$ \\
\hline PHASE 3 medium risk & $25-50 \%$ & $\begin{array}{l}\text { 1. patients with respiratory } \\
\text { symptoms, } \\
\text { 2. others. }\end{array}$ & $\begin{array}{l}\text { noticeable effects; all beds in the } \\
\text { hospital and in the ICU for the } \\
\text { infected }\end{array}$ & $\begin{array}{l}\text { 1. emergency procedures, } \\
\text { 2. oncological procedures, if the } \\
\text { prognosis is significantly worse } \\
\text { within } 3 \text { months, neoadjuvant } \\
\text { treatment cannot be applied and } \\
\text { no long ICU stay is expected. }\end{array}$ \\
\hline PHASE 4 high risk & $50-70 \%$ & $\begin{array}{l}\text { 1. patients with respiratory } \\
\text { symptoms, } \\
\text { 2. others. }\end{array}$ & $\begin{array}{l}\text { significant effect on the personnel } \\
\text { and ICU availability }\end{array}$ & emergency procedures only \\
\hline PHASE 5 emergency & $>75 \%$ & $\begin{array}{l}\text { 1. patients with respiratory } \\
\text { symptoms, } \\
\text { 2. others. }\end{array}$ & $\begin{array}{l}\text { major effect on personnel and } \\
\text { ICU availability; reduction of } \\
\text { mechanical or surgical ventilation } \\
\text { capacity or rapid increase in } \\
\text { infected persons }\end{array}$ & $\begin{array}{l}\text { emergency procedures that will } \\
\text { end in death if the delay is more } \\
\text { than a few hours preoperative } \\
\text { triage shall be conducted based on } \\
\text { adopted principles }\end{array}$ \\
\hline
\end{tabular}

In cases of emergency and urgent procedures where rapid immune tests or RT-PCR are not possible, it should be assumed that every operated patient is infected with SARS-CoV-2. Only patients with a negative epidemiological history and tested with the RT-PCR test may constitute a lower risk group (early stage of infection, asymptomatic patients). This assumption is based on the rapid growth of new infections and the need to protect medical personnel.

Operations carried out in pandemic areas are included in the higher risk group. Moreover, the procedures performed on the respiratory system can be included here - increased amount of aerosol formation (airborne transmission) [12]. The presence of RNA of the virus has also been confirmed in the digestive tract. Because of that, endoscopic procedures were also classified as high-risk, similarly to classic and laparoscopic operations of the small and large intestine [13].

In case of urgent interventions, a higher perioperative risk should be assumed in patients with a positive epidemiological or symptomatic history (fever, coughing, sore throat). If this does not represent an increased risk, the surgeon should consider whether to postpone the procedure, at least until the RT-PCR test has been performed. If any delay should result in unacceptable risk to the patient, the procedure should be performed immediately, and a positive SARS-CoV-2 status assumed.

Intubation is one of the most risky stages of operation, regardless of the SARS-CoV-2 status. In case of emergency and urgent procedures, it is recommended to perform all procedures in an at least N95 FFP3 half mask and surgical mask, and using direct eye protection (goggles/glasses) with a face-shield. All personnel not actively involved in the intubation and extubation procedure should leave the operating room for the duration thereof. The PPE should also be used by the cleaning personnel after the procedure [12].

Any patient qualified for emergency surgery should be treated as suspected of infection (Fig. 1). In the case of CT scan of the abdominal cavity performed in ER settings - it is advisable to extend the examination by including CT scan of the thorax. In cases where non-operative treatment is also possible (uncomplicated acute cholecystitis, Hinchey I-II diverticulitis, etc.), conservative therapy should be provided.

\section{TYPES OF PERSONAL PROTECTIVE EQUIPMENT DURING COVID-19 PANDEMIC}

Personal protective equipment (PPE) is required for each "close contact", which includes surgical procedures, as well as other procedures taking place in the operating theater, e.g. intubation, regional anesthesia, intravenous access etc. It is worth stressing that an increased risk of SARS-CoV-2 infection is also present when performing endoscopic examinations and procedures, particularly in the upper gastrointestinal tract [14-18].

Due to the high risk of personnel infection, we propose security measures corresponding to the third level of protection (according to the four-stage ANSI (American National Standards Institute)/AAMI PB70:2012 classification according, to the division presented in Tab. III.

Discussion of personal protective equipment:

1. A mask for an operated patient. Surgical mask to reduce the emission of aerosol exhaled from the airways, containing virus particles. An N95 mask in which the letter N indicates that the product is not resistant to oil. In addition, there are also types $\mathrm{R}$ (resistant to oil) and $\mathrm{P}$ (strongly resistant to oil). The number 95 (in N95) indicates the air particle filtration level (95\%). There are also products marked as 99 (99\%) and 100 (99.97\%). The phrase FFP (in FFP3) means "filtering facepiece", meaning a filtering half mask. FFP2 or FFP3 is the filtration class/level (there is still FFP1). FFP2 captures at least $94 \%$ of the particles at up to $0.6 \mu \mathrm{m}$ and FFP3 at least $99 \%$ of the particles at up to $0.6 \mu \mathrm{m}$. So the N95 FFP3 mask means that it is a filtering half mask that is not resistant to oily particles, the air particle filtration level in the air is $95 \%$ (considering any particles), and the filtration class is at the highest level, the third of the three possible. This means that it captures at least $99 \%$ of particles smaller than 0.6 $\mu \mathrm{m}$. Valveless masks are preferred because a ventilated mask 


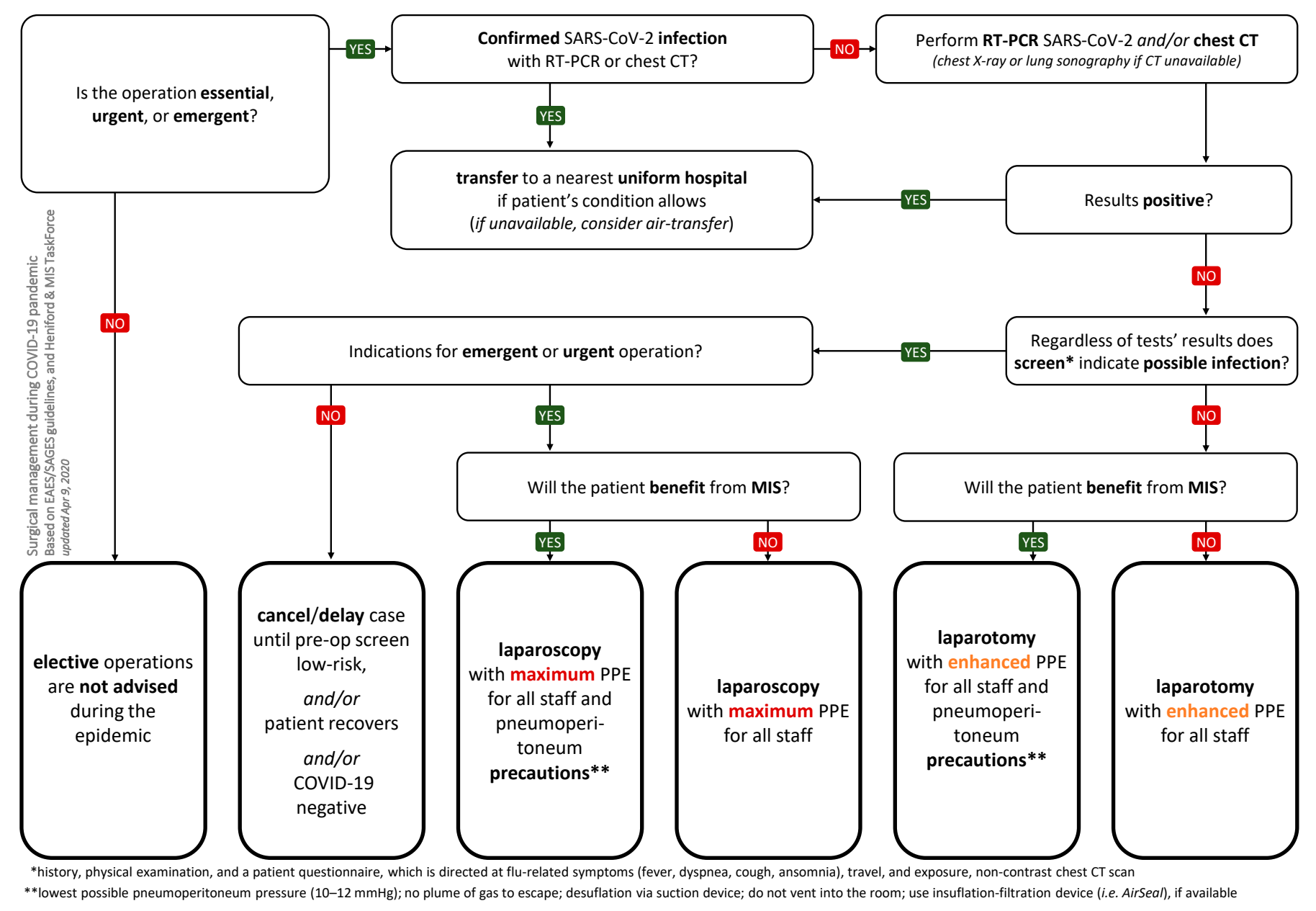

Fig. 1. Surgical procedure algorithm during COVID-19 pandemic.

does not protect the patient from operator pathogens. If only valve masks are available, an ordinary surgical mask should be worn on top of such a mask. For ease of use, we always recommend wearing a surgical mask on the mask. According to the manufacturers' instructions for use, FFP2 masks do not protect against airborne viruses;

2. Surgical cap - standard. It is not required when using a protective suit. When using a surgical gown, two can be used (the second for goggles and mask straps). In case of no suit, it is recommended to use an astrocap (covers the neckline and neck) and an additional neck wrap;

3. Surgical goggles with an elastic strap or temple glasses, fully covering the orbit area. If it is necessary to use corrective glasses, goggles shall be placed on our own glasses. (Correction glasses and glasses should be decontaminated like all other equipment). For contact lens wearers, the risk of contact lenses being displaced or falling out during surgery, without the possibility of correcting their position with the PPE used, shall be taken into account.) There is currently no scientific evidence that contact lenses should be discontinued, but they are not recommended [19, 20];

4. Visor or face-shield. Protects the face from splashing. Mounted on the head, adjustable in the back of the fastener;

5. Disposable biological protection suit with a hood tightly surrounding the face and chin, waterproof, barrier. The suit with security level 4 according to four-stage ANSI/AAMI PB70:2012 classification. Orange suits, reusable, are designed for emergency medical services and are not adapted to work indoors for a long time and under the influence of increased temperature (surgical lamp, additional sterile gown outside). White barrier suits are preferred. It is advisable to use a suit of at least one size larger, which makes it easier to put on and take off the suit. In case of using high protective rubber footwear, we choose a model of the suit without the feet (suit leg outside the wellington). When using short boots, overalls with integrated foot protectors are preferred. Some of the suits have separate high foot protectors, tied at shin level. Such a solution is an alternative to the wellingtons;

6. Surgical gown - sterile, barrier, class 4 . If the suit is not available, a waterproof barrier gown (class 4), in accordance with EN 13795-1 is preferred. If a barrier suit is worn, it may be a normal one. In the absence of a barrier suit, a foil gown can be used under the suit. In addition to its barrier properties against infectious agents, the clothing material for protection against biological agents should exhibit adequate mechanical resistance in terms of abrasion, tear and bending, among other things. All material properties are presented in the standard PN EN 14126 as classes as in most European standards;

7. Surgical gloves. If the suit is worn: the first pair, placed on the sleeves of the suit, is longer, up to at least $1 / 3$ of the forearm (extended gloves used in gynecology); the second and the third pair is put on the surgical gown; 
Tab. III. Types of personal protective equipment sets.

\begin{tabular}{|c|c|c|c|}
\hline $\begin{array}{l}\text { PPE FOR INVASIVE } \\
\text { PROCEDURES }\end{array}$ & STANDARD & EXTENDED & MAXIMUM \\
\hline indications & low risk & moderate risk & high risk \\
\hline mask & $\begin{array}{l}\mathrm{N}_{95} \mathrm{FFP}_{3} * \text { and } \\
\text { surgical mask }\end{array}$ & $\begin{array}{l}\mathrm{N}_{95} \mathrm{FFP}_{3} \text { and } \\
\text { surgical mask }\end{array}$ & $\begin{array}{l}\mathrm{N}_{95} \mathrm{FFP}_{3} \text { and } \\
\text { surgical mask }\end{array}$ \\
\hline headgear & cap & $\begin{array}{l}\text { astrocap with } \\
\text { head and neck } \\
\text { protection }\end{array}$ & $\begin{array}{l}\text { waterproof cap or } \\
\text { hood }\end{array}$ \\
\hline eye protection & $\begin{array}{l}\text { goggles or safety } \\
\text { glasses }\end{array}$ & $\begin{array}{l}\text { goggles or safety } \\
\text { glasses and visor }\end{array}$ & $\begin{array}{l}\text { goggles or safety } \\
\text { glasses and visor }\end{array}$ \\
\hline trunk protection & $\begin{array}{l}\text { barrier surgical } \\
\text { gown }\end{array}$ & $\begin{array}{l}\text { double-barrier } \\
\text { surgical gown }\end{array}$ & $\begin{array}{l}\text { one-piece } \\
\text { biological } \\
\text { protection suit and } \\
\text { surgical gown }\end{array}$ \\
\hline hand protection & $\begin{array}{l}\text { disposable gloves } \\
\text { consider double }\end{array}$ & $\begin{array}{l}\text { double }(\mathrm{x} 2) \\
\text { disposable gloves }\end{array}$ & $\begin{array}{l}\text { triple }(\times 3) \\
\text { disposable gloves }\end{array}$ \\
\hline leg protection & shoe protection & $\begin{array}{l}\text { high protection } \\
\text { boots }\end{array}$ & $\begin{array}{l}\text { high protection } \\
\text { boots, if the } \\
\text { protection suit } \\
\text { does not protect } \\
\text { your feet }\end{array}$ \\
\hline
\end{tabular}

* in patients operated on in an expedited mode after a week-long isolation with a negative RT-PCR and CT scan of the thorax, an exceptionally lower protection level (e.g. FFP2) is allowed when $\mathrm{FFP}_{3}$ masks are not available.

8. Safety footwear. Without holes and perforated surfaces. Full boots. Uniform, extended rubber boots (wellingtons) are the best ones. Foil protectors can be used on the outside of the shoes - sole protection, useful when moving to the clean zone (after removing the protectors the soles are clean and you can use them to step in the lock. By putting on a second pair of foil protectors on your feet, you can take off the wellingtons and go to the shower area without sole skin touching the ground and without having to use separate footwear to go there.

\section{USE OF PERSONAL PROTECTIVE EQUIPMENT}

The purpose of personal protective equipment (PPE) is to protect the personnel against infection in places where biological hazards may occur $[17,21-60]$. The use of personal protective equipment in the form of a suit or waterproof long-sleeve barrier gown is identical and interchangeable. This means that the operation can be performed either in an overalls with a sterile gown or in a double barrier gown. In the latter case, however, it is important to note the need for an additional neck and neckline cover (e.g. an astrocap). However, it is recommended that you do not start the surgery with a suit. Before using any PPE, please read the manufacturer's operating instructions. Selected PPE should be one size larger for more freedom of movement. It is mandatory to use the bathroom each time before putting PPE on. It is admissible to stay barefoot in the suit. It is not advisable to put a disposable cap underneath the suit, as this makes the process of taking off the PPE considerably more difficult and increases the risk of infection. It is permitted to wear the suit when seated, but it can only be removed when standing. Do not hurry. Every movement when putting on and, in particular, taking the PPE off, must be gentle, cautious and thoughtful. Each movement must be controlled by looking in the mirror, ideally with an assistant reading the subsequent commands. In case of no assistance, read the next commands aloud. All the elements of the PPE are to be prepared and arranged according to an internally adopted scheme so that everyone knows where to get specific items from. It is highly recommended to practice putting PPE on and taking it off, even at the cost of using PPE for this purpose. Optimally, every employee should practice the procedure of putting PPE on and taking it off. It is permitted to use a filtering half mask, N95 FFP3 type only, with or without a valve under operating theater conditions [46]. When using the N95 FFP3, make sure it adheres tightly to the face along the entire circumference of the mask and is surely secured with rubber bands at the back of the head. It is necessary to fit the mask tightly over the nose by pressing the metal strap on the upper edge of the mask. After the mask has been worn, a tightness test should be carried out by means of a short forced exhalation; no air leakage around the mask indicates a good fit.

When preparing for work, take the following notes into account $[17,30,31,35-38,55-60]$. The hair should be secured with a hair tie. The facial hair should be shaved. Nails should be shortened and nail polish removed from the nail plates. It is forbidden to wear artificial fingernails. Only one mobile phone, stamp, corrective glasses are allowed on personal equipment. It is recommended that the corrective glasses are on the attachment strap/strips. It is forbidden to put socks and undershirts under disposable hospital clothing. It is forbidden to use your own stethoscope and your own pen. It is forbidden to use any pins, bobby pins, brooches or any hair decorations. It is forbidden to put on earrings, clips, rings, wedding rings, signets, necklaces, chains or any other jewelry.

The rules concerning the use of appropriate clothing shall be observed [17, 30, 31, 35-38, 55-60]. The shoes must be full, washable, without holes, cavities or perforations, and disinfected by the hospital after each day of work. Use disposable clinical clothing, which is thrown in a red bag basket after each day of work. Surgical mask is mandatory throughout the entire department.

The detailed discussion of procedures concerning the use of personal protective equipment can be found in Annexes 1, 2, 3 available on the website of the Video Surgery Section of the Polish Society of Surgeons - wideochirurgia.tchp.pl [17, 21-60].

\section{ORGANIZATION OF THE SURGERY DEPARTMENT DURING THE COVID-19 PANDEMIC}

There are no nationwide uniform recommendations for treatment in hospitals which are neither infectious nor special COVID-19 hospitals. The document was developed on the basis of measures of proven effectiveness from the cited literature that can be effectively implemented in Poland. The department is an integral part of the hospital and cannot operate independently. It is required to implement measures throughout the entire hospital and all departments necessary for its operation. The aim of the organizational changes is to maintain the continuity of the department and to ensure the safety of employees and patients. Key actions include the creation and strict adherence to procedures and ensuring continuity of access to PPE [47].

All workers who are not necessary in the treatment process should stay at home or be allowed to work remotely [61]. All individual training should be canceled or, if possible, replaced by on-line classes. Only the minimum necessary number of medical personnel should be present during medical visits and other meetings. The 
principles of proper hand washing, use of antiseptic materials and personal protective equipment shall be strictly observed. In cases where individual surgical consultations are needed, all procedures should be performed only by those making the final decision on further procedures to avoid the risk of re-consultation or inconclusive consultations [47].

If the workload of surgical departments is reduced (postponement of scheduled procedures), it should be considered to divide the surgical team into two or three smaller rotating teams, which will have no contact with each other, which in the case of infection/ quarantine could enable to maintain further work for patients [61].

The department is divided into a standard section and an observation sub-department. In the standard section, there are patients with negative $\mathrm{CoV}-2$ test results and the personnel uses the PPE as in the low risk group (Internal procedure - PPE in the low and high risk group) [62].

In the observation sub-department, patients admitted temporarily in single rooms are hospitalized and treated until a CoV-2 test result is obtained. These patients are treated as high-risk patients until a test result is obtained, and personnel uses PPE as in the high-risk group. If the rooms do not have their own bathrooms, patients go out only to the bathroom; there can only be one patient in the hallway and the bathroom. Medical orders and nursing procedures are planned in a way that minimizes the number of entries to the room and the time of personnel contact with the patient. In case of a CoV-2(-) result, the patient is transferred to the standard department. With a CoV2(+) result, the attending physician directs the patient to further treatment in a special COVID-19 hospital. Nursing and ward attendant personnel (or persons exercising their functions) of the observation sub-department shall be appointed by the directorate and shall be provided with full protection for their safety. The team consisting of one nurse and one ward attendant remains on duty for 12-24 hours for all patients in the department, with complete protection during the procedures. The people in this team do not work in other parts of their hospital. The visit (if necessary) and the medical intervention is carried out by the Senior Physician on duty after changing into PPE. Patients wear surgical masks when medical personnel is present in the room and when going out to the bathroom. The hospital shall establish an internal procedure to disinfect bathrooms during the day and rooms after the $\mathrm{CoV}-2(+)$ patient leaves them. It is possible to create one observation department per several standard departments (e.g. surgery, internal medicine, orthopedics, etc.). The work is organized in such a way as to minimize the maintenance of records [47].

\section{Managing a team of medical personnel}

Confirmation of contact with the virus eliminates an employee or group of employees from work or results in a department being closed, while in case of patients it results in a transfer to an observation department or discharge home if their health condition allows it. On the other hand, failure to meet the contact criteria precludes the introduction of the foregoing actions towards employees and patients [61]. The contact is constituted by staying with a CoV-2(+) person in one room without PPE for more than 15 minutes at a distance of less than 2 meters or to perform any medical procedures without PPE appropriate for the patient's current status. Every employee is subject to temperature measurement at the hospital entrance. An employee with a temperature above $37.5^{\circ} \mathrm{C}$ or symptoms of respiratory tract infections is sent home with the implementation of appropriate epidemiological and diagnostic procedures. The employee shall inform his or her superior. The superior shall organize substitution. Until the time of substitution, the current on-call duty remains [61]. Every employee shall use a surgical mask from the moment of entering the workplace, maintain the distance of two meters, avoid being in the same room with another employee for more than 15 minutes $[48,53,62]$. All findings, recommendations, consultations and reports are recommended to be communicated by telephone or e-mail. The contact between the personnel and the patient takes place only with appropriate protection (dressing procedure at work) [53].

Employees are obliged to limit contact with patients to one hospital only. This excludes the possibility of working with patients in another center. Working in two healthcare centers increases the risk of contact, i.e. spreading the virus and closing our hospital.

\section{Documentation flow}

During the pandemic, the flow of paper documentation shall be stopped. Medical orders for nurses, the performance of which must be confirmed by the signature and stamp of the doctor and the nurse, constitute an exception. The need to confirm medical procedures is limited to drug delivery procedures and procedures with integumentary integrity being breached, and approval of medical and nursing reports. The need for confirmation of measurement and monitoring results shall be suspended. The medical documentation previously remaining in the patient's room shall be transferred entirely to the nurse room or other room in the department [61]. This is achieved by sending documentation electronically.

\section{ADAPTATION AND ORGANIZATION OF THE OPERATING THEATER}

Recommendations for a standard hospital:

- separate operating theater or $\mathrm{CoV}$ zone and operating room (for patients without symptoms of COVID-19 waiting for a CoV-2 test result) so as to limit transmission routes and theater contamination;

- separate operating theater or zone and operating room for SARS-CoV-2 negative patients.

Recommendations for a special COVID-19 hospital:

- separate operating theater or COVID zone (for patients with confirmed SARS-CoV-2 and patients with highly probable positive viral result based on imaging tests), so as to limit the transmission routes and theater contamination;

- separate the operating area and operating room for patients without $\mathrm{CoV}-2$ confirmation in the test and without characteristic changes for COVID-19 in the imaging tests;

- separate areas for quarantine patients, if possible;

- separate at least two operating rooms for the COVID zone (interchangeable surgical procedures, possibly different specialties e.g. general and trauma surgery). 
Universal recommendations $[47,61,63-66]$ :

- divide the operating theater into purity zones: (1) green (clean) zone - assumed SARS-CoV-2-free zone (operating theaters and theater rooms for SARS-CoV-2-negative patients - normal operating theater mode; (2) yellow zone - restricted access zone; (3) orange zone - barrier and airlock zone, used to hand over equipment and take off protective outerwear; (4) red zone (contaminated) - operating rooms for SARS-CoV-2-positive patients; (5) violet zone - areas where access is strictly prohibited during activities concerning SARS-CoV-2-positive patients;

- clear and transparent color coding of the rooms in the operating theater;

- if available, use vacuum-controlled rooms within the patient premises, particularly in the operating room;

- leave only the necessary equipment to carry out the operation in the CoV and COVID operating theaters, taking the equipment not being used to the green zone;

- protection against contamination of equipment that cannot be removed from the room (e.g. protective film, easily washable covers);

- preparation of universal, uniform sets on mobile trolleys stored in the green area: (1) surgical tools (laparotomy, laparoscopy) to perform standard operating procedures, it is recommended to use automatic hooks and other methods to reduce the number of necessary personnel; (2) for anesthetic procedures (anesthesia, central punctures);

- it is necessary to plan procedures well, predict the equipment necessary and desirable for the type of a given procedure so as to limit the amount of equipment transferred to the room, but also the equipment that will be subject to decontamination;

- if it is necessary to use additional equipment during the procedure, it is recommended to bring it in before the patient enters the operating room;

- preparing clear instructions on where to cross the individual zones;

- if possible, the use of laminar positive pressure air flow (negative pressure is only recommended if the theater is designed in this way, otherwise there is a risk that polluted air from corridors, technical space, ventilation shafts, suspended ceilings, etc. will be sucked into operating theaters in a way that is difficult to predict);

- prohibition to store medical records (including anesthesia reports) in operating rooms (all records available in the operating theater only in the green zone, possible copies of e.g. blood types, are brought into the red zone, later destroyed without leaving the red zone). The personnel shall read the documentation before entering the room. In the operating room, there is only documentation created there (e.g. anesthesia report, perioperative control report), after the completion of surgery, each document is placed in a sealed clean foil/plastic pocket and attached to the medical history in this form;

- during the surgical procedure, only personnel directly involved in the operation remains in the operating room and no one shall leave the room. Optimally, the operating team includes: operator, assistant, anesthesiologist, nurse anesthetist, the so-called "clean" and "dirty" scrub nurse;

- in addition, outside the operating room, the following personnel shall be delegated for CoV or COVID surgery (one or more persons as required, performing the following tasks): in the yellow zone: coordinator or messenger; in the green zone: coordinator of the entire procedure, nurse anesthetist, scrub nurse, X-ray technician, messenger.

The following procedures need to be established:

- admission of the patient to the theater (route of entry, admitting personnel, notification);

- actions during the procedure (supplying additional material and equipment, sending specimens for testing);

- completion of the procedure and departure of the patient;

- cleaning the room, operating tracts and preparation for the next procedure;

- proceedings in case of necessity of sudden leaving the red zone;

- proceedings in case of violating the rules of personal protective equipment use;

- proceedings in case of violating the zone cleanliness;

- when establishing procedures and planning work, the hierarchy of priorities must be kept in mind: the safety of personnel is paramount, patient safety is second and zone safety is third.

\section{ORGANIZATION OF PATIENT TRANSPORT ROUTES}

There is a need to take over the patient from the emergency medical service teams, as well as to provide the internal transport of the patients within each healthcare facility. For safety reasons, the transport of patients with confirmed SARS-CoV-2 infection shall be kept to a minimum and designated internal transport routes shall be followed.

If possible, horizontal and vertical (between floors) passageways should be determined only for the transport of patients infected with or suspected of COVID-19 infection [61, 67].

\section{Taking over the patient from the emergency medical service team-general rules}

- The patient shall be placed in a room dedicated for initial assessment and therapy of patients infected or suspected of being infected with SARS-CoV-2, equipped with medical devices for monitoring of cardiopulmonary and respiratory parameters, airway opening, including closed-circuit vacuum suction pump, and drugs according to the internal procedure (usually standard equipment in the resuscitation room of the Hospital Emergency Department). Patients suspected of being infected with SARS-CoV-2 shall be introduced or brought in using a different entrance, separate from the confirmed cases;

- All personnel participating in the admission shall wear personal protective equipment.

\section{Transfer of patient to ward, operating theater, ICU}

\section{Patient safety}

- A patient with signs of threatening or developing respiratory failure shall be placed in a department providing mechanical ventilation capabilities as early as possible; 
- Assessment of necessity and, if necessary, performance of endotracheal intubation before transport of the patient;

- If required by the general condition of the patient, in addition to the nurse, the patient should be accompanied by a doctor when transported. The team responsible for patient transport shall be prepared for cardiopulmonary resuscitation;

- The patient shall be monitored (saturation and blood pressure are to be assessed during transport, the record of lead II shall be constantly visible on the screen);

- Capnography shall be used in case of an intubated patient;

- During transport, the defibrillator can be used to monitor the patient, and if another monitoring device is used, the defibrillator shall be continuously available.

\section{Safety of medical and transport personnel}

- Personnel involved in patient transport must wear personal protective equipment;

- All employees involved in transport must wear N95 FFP3 masks;

- If the patient is not intubated, he or she should wear a surgical mask, properly fitted to the face, so that it covers the mouth and nose;

- Use a HEPA filter connected to the endotracheal tube if mechanical breathing with a bag valve mask is required;

- During transport, the use of open oxygen therapy systems shall be reduced, thus reducing the risk of aerosol formation;

- For a patient who is being transported with mechanical breathing, the HEPA filter shall be placed on the air outlet tube;

- Prior to transport, the risk of disconnection of airflow system components shall be reduced by reassessing the connections and their tightness, and additional safeguards against accidental disconnection of system components shall be considered (e.g. by adhesive bonding).

\section{Safety of bystanders}

- Transportation of infected and suspected patients shall be carried out by routes that have been clearly and legibly marked beforehand, according to an internal procedure;

- As far as possible with regard to organizational capabilities in a specific unit, prior to transporting the patient, designated persons (usually auxiliary personnel, e.g. medical assistants, ward attendants, paramedics or volunteers working in the fight against the epidemic) who are not directly involved in patient care should check whether the route is free of congestion, remove bystanders and notify the doctor ordering or directly supervising the transport about its protection. These persons shall wear surgical masks at least, and not be in the way of patient transport. We are aware that these conditions are currently difficult to implement in most sites, so they should only be treated as a guide to organizational changes, not a strict recommendation.

\section{OPERATING TECHNIQUE}

During the COVID-19 pandemic, the choice of the optimal surgical technique is one of the most common clinical questions asked by surgeons. The data available in the literature concerning the foregoing is limited to studies of low reliability but is constantly updated with new reports.
Based on the current state of knowledge, the transmission of SARS$\mathrm{CoV}-2$ takes place through contact with secretions and through airborne transmission, and the fecal-oral pathway has not been explicitly ruled out $[68,69]$. The potential for infection route and the risk of contamination shall therefore be considered during surgical treatment. Therefore, surgical teams are advised to scrupulously use adequate personal protective equipment to reduce the risk of infection, regardless of the surgical technique being used.

\section{Basic operation technique recommendations}

\section{Electrosurgery}

When using electrocoagulation tools, aerosol formation during the operation may occur from the released particles and fluids. Because of that, the use of monopolar, ultrasonic and advanced bipolar tools shall be (reasonably) minimized. When using surgical power tools, the lowest possible operating parameters shall be used while maintaining the desired effect.

If possible, a monopolar diathermy with a smoke evacuation system shall be used in the open approach operation, or smoke shall be evacuated by an assistant (filter on the suction unit is necessary)

\section{Surgical approach}

At present, we do not have clear evidence on the relative risk of laparoscopy compared to laparotomy (open surgery) in patients infected with SARS-CoV-2 [70, 71]. Although studies on HBV viruses have shown that laparoscopy may lead to the formation of an aerosol containing virus molecules from the patient's blood, there is no clear evidence that a similar effect is present in the case of coronavirus, particularly since patients with SARS-CoV-2 infection do not show the presence of the virus in the blood [72]. All the more so, there is no evidence that such an effect could only be associated with minimally invasive procedures. Based on the suppositions that SARS-CoV-2 could potentially be released in the form of an aerosol in carbon dioxide used to produce pneumoperitoneum, Di Saverio et al. stated that the decision concerning the use of laparoscopy should be made individually with regard to the patient, disease and surgeon's experience [73]. At the same time, the authors emphasized that laparoscopy, carried out in an enclosed space of the abdominal cavity, can reduce the spread of aerosol in relation to open surgery, while maintaining the tightness of the system and the removal of carbon dioxide from the abdominal cavity using a vacuum suction unit. Mintz et al. [74] presented an inexpensive and effective method of removing gas from the peritoneal cavity using the filter used for ventilators; they stressed that laparoscopy may be the preferred method, as during classical surgery there is no possibility of full control over the smoke released when using electrosurgical instruments.

Therefore, in view of the availability of inexpensive and effective methods of purifying the gas used for laparoscopy, it is stressed that purifying the air from aerosol particles can be much more difficult during open surgery. Additionally, laparoscopy creates a natural physical barrier between the personnel and the potential source of infection, thus reducing the surgical team's exposure to the patient's body fluids and risk of occupational exposure. Moreover, one should remember about well-documented advantages of minimally invasive surgery, 
such as reduced number of complications (including pneumonia) and reduced mortality, which may be particularly important for patients with COVID-19, as well as reduced hospitalization time, which cannot be overestimated in epidemic conditions [75].

Taking into account the data presented above, the following is recommended during laparoscopic surgeries:

- preoperatively check the correct operation of laparoscopic equipment (trocars, seals, etc.);

- plan and make the smallest possible notches for the introduction of the trocars, ensuring that they are tightly sealed around;

- maintain intra-abdominal pressure of 8-11 mmHg;

- evacuate the smoke during the operation via a suction unit connected to a central vacuum system and/or use smoke filters (for this purpose, respirator filters connected via an adapter may also be used);

- before making an additional incision (e.g. minilaparotomy), perform desuflation using the techniques described above;

- avoid keeping the patient in the Trendelenburg position for an extended time.

To sum up, classical and laparoscopic operations can be performed during COVID-19 pandemic when maintaining precautions concerning pneumoperitoneum (Tab. IV.) [76-79]. The surgical technique shall be adapted to the patient, the disease to be treated and the experience of the operator.

\section{Stoma}

Note that stoma formation (temporary or permanent) carries an increased risk of transmission, which should be considered by both hospital personnel and family members. The indications for stoma formation during the COVID-19 pandemic remain unchanged compared to the basic surgical indications.

\section{Peritoneal drainage}

Given that transmission of SARS-CoV-2 infection via body fluids has not been ruled out, the use of surgical drains should be restricted as far as possible, and closed systems should be used if necessary. It should be emphasized that the foregoing recommendations do not differ significantly from the standard recommendations of "modern surgical practice" used on a daily basis in surgical departments in Poland.

Operating rooms intended for patients with suspected or confirmed SARS-CoV-2 infection shall be adequately filtered and ventilated. If possible, these rooms shall be dedicated exclusively to this patient group, being different from those used for other urgent operations. Use negative-pressure rooms, if available. Surgical equipment that has been used during procedures in patients with positive SARS-CoV-2 results, patients undergoing diagnostics and patients with suspected infection shall be sterilized separately from other instruments. However, use disposable equipment and tools where possible. During the treatment of suspected/infected patients, the number of personnel present in the operating room shall be reduced to an absolute minimum. If possible, the operation should be performed by an experienced surgeon. Due to the expected increasing number of asymptomatic patients requiring
Tab. IV. Summary of guidelines of international surgical societies in the assessment of surgical approach technique used during COVID-19 pandemic [76-79]

\begin{tabular}{|c|c|c|}
\hline $\begin{array}{l}\text { DATE OF } \\
\text { PUBLICATION }\end{array}$ & ORIGIN OF THE GUIDELINES & $\begin{array}{l}\text { EVALUATION OF THE BENEFITS } \\
\text { OF THE TECHNIQUE USED }\end{array}$ \\
\hline Mar 26, 2020 & Royal College of Surgeons of England & laparoscopy < laparotomy \\
\hline Mar 29, 2020 & $\begin{array}{l}\text { Society of American Castrointestinal } \\
\text { and Endoscopic Surgeons }\end{array}$ & laparoscopy = laparotomy \\
\hline Mar 30,2020 & $\begin{array}{l}\text { European Association } \\
\text { for Endoscopic Surgeons }\end{array}$ & laparoscopy = laparotomy \\
\hline Apr 04, 2020 & $\begin{array}{l}\text { Spanish Association } \\
\text { of Surgeons }\end{array}$ & laparoscopy > laparotomy \\
\hline
\end{tabular}

surgical intervention, the foregoing principles shall be applied in each case to reduce the possibility of infection within the teams.

\section{MODIFICATIONS OF PHARMACOTHERAPY AND NUTRITIONAL TREATMENT OF PATIENTS WITH CONFIRMED COVID-19}

In the case of surgical patients with COVID-19, great attention should be paid to the nutritional status, especially if extensive surgery is planned, in elderly people and/or with accompanying conditions or if the procedure has been performed in urgent mode. Early assessment of the nutritional status and applying nutritional treatment on time improve the patient prognosis [80]. Patients with a high risk of complications and a higher risk of dying as a result of SARS-CoV-2 infection, especially with associated diseases and in old age, should have their nutritional status assessed. Use an oral diet wherever possible. The first step should be dietary advice. Advice shall be provided by an experienced specialist (dietician, nutritionist, doctor with experience in nutritional treatment). Industrial oral diets [Foods for Special Medical Purposes (FSMP); formerly: oral nutritional supplements, (ONS)] shall be used in any case if dietary advice and diet fortification are unable to provide an increase in the supply of nutrients and achieve a nutritional treatment goal. They shall be used to provide at least $400 \mathrm{kcal} /$ day and 30 (or more) grams of protein per day. Treatment shall be continued for at least one month, the effectiveness of the treatment should be assessed only after that period (and performed every month). Enteral nutrition (EN) by artificial access is the intervention of choice when oral nutrition is insufficient or impossible. Early introduction of enteral nutrition provides nutritional support, intestinal nutrition, improvement of intestinal mucosal barrier and intestinal immunity, and contributes to the preservation of gastrointestinal bacterial flora. In intubated patients, the only feeding method is often the use of a probe placed behind the pylorus. Despite the reported doubts about increased risk of SARS-CoV-2 infection in patients with the probe inserted into the gastrointestinal tract, such a correlation has not been confirmed so far [81]. Complete protein preparations may be used in patients with properly functioning gastrointestinal tract. Oligopeptide diets are recommended for patients with impaired gastrointestinal absorption. It is possible to supply them using an infusion or gravitational pump, with indication of the former. It is also the method of choice for the enteral nutrition. The inclusion of parenteral nutrition (PN) shall be considered in a situation where EN is insufficient or contraindicated. If the patient is not malnourished, the inclusion of the PN is considered after 7 days of ineffective EN. The treatment of SARS-CoV-2 infection depends on the severity of the disease. There are four levels of progression: mild, moderate, severe and very severe (critical phase) [61, 82]. 
The protocols of the proceedings are presented in a publication by Liang et al. [61]. The management of sepsis and septic shock is described in the Surviving Sepsis Campaign Guidelines [82]. These publications contain detailed guidelines for patient treatment.

In brief, it should be stressed that the basis of pharmacotherapy is early antiviral treatment, supported by glucocorticosteroids and antibiotic

\section{REFERENCES}

1. McKay B., Calf as J., Ansari T.: Coronavirus declared pandemic by World Health Organization. The Wall Street Journal, March 11, 2020.

2. Dz. U. 2020 poz. 422. Rozporządzenie Ministra Zdrowia z dnia 12 marca 2020 r. w sprawie sposobu i trybu finansowania z budżetu państwa świadczeń opieki zdrowotnej wykonywanych w związku z przeciwdziałaniem COVID-19.

3. Cheng Z.J., Shan J.: Novel coronavirus: where we are and what we know. Infection., 2019; 2020 [Feb 18, Epub ahead of print].

4. „Koronadomino” zabiera szpitalom personel medyczny. Puls Medycyny. 2020.04.02 źródło: https://pulsmedycyny.pl/koronadomino-zabiera-szpitalom-personel-medyczny-987122.

5. Cheung J.C., Ho L.T., Cheng J.V. et al.: Staff safety during emergency airway management for COVID-19 in Hong Kong.

6. Legido-Quigley H., Mateos-Garcia J., Campos V. et al.: The resilience of the Spanish health system againt the COVID-19 pandemic. Lancet Public Health. 2020 Mar 18. Doi: 10.1016/S2468-2667(20)30060 - Epub ahead of print.

7. SAGES and EAES Recommendations Ragarding Surgical Response to COVID-19 Crisis. 30/03/2020. (https://www.sages.org/recommendations-surgical-response-covid-19/).

8. American College of Surgeons. COVID-19: Elective Case Triage Guidelines for Surgical Care. Online March 242020 (https://www.facs.org/covid-19/clinical-guidance/elective-case).

9. Xiao F., Tang M. et al.: Evidence for gastrointestinal infection of SARS-CoV-2. Gastroenterology., 2020 Mar 3 doi: S0016-5085(20)30282-1 (Ahead of print).

10. Yeo D., Yeo Ch., Kaushal S., Tan G.: COVID-19 \& the General Department Measures to reduce spread of SARS-CoV-2 among surgeons. Annals of Surgery. (https://journals.lww.com/annalsofsurgery/Documents/COVID-19\%20 and\%20the\%20General\%20Surgical\%20Department.pdf).

11. Adhikari S., Meng S., Wu Y. et al.: Epidemiology, causes, clinical manifestation and diagnosis, prevention and control of coronavirus disease (COVID-19) during the early outbreak period: a scoping review. Infect Dis Poverty., 2020 Mar 17; 9(1): 29.

12. Zou L., Ruan F., Huang M. et al.: SARS-CoV-2 Viral Load in Upper Respiratory Specimens of Infected Patients. New England Journal of Medicine., 2020; 382(12): 1177-1179.

13. Wu Y., Guo C., Tang L. et al.: Prolonged presence of SARS-CoV-2 viral RNA in faecal samples. Lancet Gastroenterol Hepatol., 2020.

14. https://www.who.int/news-room/detail/03-03-2020-shortage-of-personalprotective-equipment-endangering-health-workers-worldwide

15. https://www.who.int/csr/resources/publications/PPE_EN_A1sl.pdf?ua=1

16. https://www.cdc.gov/coronavirus/2019-ncov/

17. Guidance for wearing and removing personal protective equipment in healthcare settings for the care of patients with suspected or confirmed COVID-19. ECDC: Stockholm; 2020. https://www.ecdc.europa.eu/sites/default/files/documents/COVID-19-guidance-wearing-and-removing-personal-protectiveequipment-healthcare-settings-updated.pdf

18. https:/www.ecdc.europa.eu/sites/default/files/documents/Cloth-face-masksin-case-shortage-surgical-masks-respirators2020-03-26.pdf

19. Jones L., Walsh K., Willcox M., Morgand P., Nichols J.: The COVID-19 pandemic: Important considerations for contact lens practitioners. https://doi. org/10.1016/j.clae.2020.03.012

20. Editorial. Contact lens practice in the time of COVID-19. https://doi.org/10.1016/j.clae.2020.03.007

21. https://asinos.pl/pl/blog/HIGIENA-RAK-W-OPIECE-ZDROWOTNEJ-CZ.-2./12

22. Godson N.: (2014-05-22). Nursing \& Health Survival Guide. ISBN 9781317906087.

23. Kilpatrick C.: „HAI \& Infection in Scotland”. Health Protection Scotland. therapy [61]. The patient's metabolic status should be monitored. From a purely surgical point of view, the clinical significance of the considerations concerning potential adverse effects of ibuprofen or other NSAIDs (non-steroidal anti-inflammatory drugs), quite often used in surgical departments, on the course of COVID-19 is of clinical importance. It should be noted that at the moment, there is no evidence of such dependence, therefore these drugs can be safely used [83].

24. „WHO Guidelines on Hand Hygiene in Health Care” (PDF). World Health Organization.

25. Ayliffe G.A., Babb J.R., Quoraishi A.H.: A test for ,hygienic' hand disinfection. J Clin Pathol., 1978; 31(10): 923-928. doi: 10.1136/jcp.31.10.923.

26. Chirurgiczna dezynfekcja rąk Metoda nacierania zgodnie z CEN/EN 12791 https://www.magazyn-stomatologiczny.pl/files/1608.pdf

27. Higieniczna dezynfekcja rąk Metoda nacierania zgodnie z CEN/EN 1500 https://www.magazyn-stomatologiczny.pl/files/1607.pdf

28. Instrukcja prawidłowego mycia rąk https://higieniczny.pl/public/assets/instrukcja-mycia-rąk.jpg

29. Instrukcja chirurgicznej dezynfekcji rąk https://higieniczny.pl/public/assets// instrukcja-dezynfekcji-rąk.jpg

30. https://apps.who.int/iris/bitstream/handle/10665/150115/WHO_HIS_SDS_2015.1_ eng.pdf;jsessionid=B4ED89744E87999E879152B522337AD9? sequence $=1$

31. https://apps.who.int/iris/bitstream/handle/10665/150116/WHO_HIS_ SDS_2015.2_eng.pdf?sequence $=1$

32. https://apps.who.int/iris/bitstream/handle/10665/150117/WHO_HIS_ SDS_2015.3_eng.pdf?sequence $=1$

33. https://apps.who.int/iris/bitstream/handle/10665/150118/WHO_HIS_ SDS_2015.4_eng.pdf? sequence $=1$

34. https://apps.who.int/iris/bitstream/handle/10665/137410/WHO_EVD_Guidance_PPE_14.1_eng.pdf?sequence $=1$

35. https://www.who.int/csr/resources/publications/PPE_EN_A1sl.pdf?ua=1

36. https://www.who.int/news-room/q-a-detail/q-a-coronaviruses\#

37. https://www.cdc.gov/coronavirus/2019-ncov/downloads/A_FS_HCP_COVID19_PPE.pdf

38. https://www.cdc.gov/coronavirus/2019-ncov/downloads/A_FS_HCP_COVID19_PPE_11x17.pdf

39. European Centre for Disease Prevention and Control. Infection prevention and control for COVID-19 in healthcare settings - Third update. $31 \mathrm{March}$ 2020. ECDC: Stockholm; 2020. https://www.ecdc.europa.eu/sites/default/files/documents/Infection-prevention-control-for-the-care-of-patients-with2019-nCoV-healthcare-settings_update-31-March-2020.pdf

40. Coronavirus disease 2019 (COVID-19) pandemic: increased transmission in the EU/EEA and the UK - seventh update, 25 March 2020. Stockholm: ECDC; 2020. https://www.ecdc.europa.eu/sites/default/files/documents/RRA-seventhupdate-Outbreak-of-coronavirus-disease-COVID-19.pdf

41. https://www.facs.org/-/media/files/covid19/considerations_optimum_surgeon_protection.ashx

42. https://www.su.krakow.pl/strefa-pacjenta/koronawirus-najwazniejsze-fakty-izalecenia\#zespol-ds-przeciwdzialania-zagrozeniom-zwiazanym-z-rozprzestrzenianiemsie-wirusa-sars-cov-2-szpitala-uniwersyteckiego-w-krakowie

43. https://www.su.krakow.pl/repozytorium-plikow/strefa-pacjenta/koronawirus/7931-zalecenia-ecdc-dotyczace-zakladania-i-zdejmowania-sroidkow-ochro ny-indywidualnej/file

44. https://cloud.gumed.edu.pl/s/XTTm8wRTws94Ptk

45. https://gis.gov.pl/wp-content/uploads/2020/03/ulotka-dezynfekcja_rąk.pdf

46. https://covid19.aischannel.com

47. Zasady postępowania chirurgicznego u pacjentów z zakażeniem Covid-19. Zalecenia Hiszpańskiego Stowarzyszenia Chirurgów (Spanish Association of Surgeons; SAS), oraz EAES (European Association for Endoscopic Surgery). Tłumaczenie: Kryspin Mitura, Marek Zawadzki, Michał Solecki, Piotr Kalinowski, Wojciech Rogula, Paweł Gajdek, Piotr Myśliwiec.

48. Handbook of COVID-19 Prevention and Treatment Compiled According to Clinical Experience. Zheijang University School of Medicine 2020. 
49. https://www.who.int/news-room/detail/03-03-2020-shortage-of-personalprotective-equipment-endangering-health-workers-worldwide

50. https://www.cdc.gov/coronavirus/2019-ncov/downloads/COVID-19_PPE_illustrations-p.pdf

51. https://www.cdc.gov/coronavirus/2019-ncov/hcp/ppe-strategy/index.html?CDC_AA_refVal=https\%3A\%2F\%2Fwww.cdc.gov\%2Fcoronavirus\%2F2019ncov\%2Fhcp\%2Fhealthcare-supply-ppe.html

52. https://www.cdc.gov/coronavirus/2019-ncov/hcp/respirator-use-faq.html

53. European Centre for Disease Prevention and Control. Personal protective equipment (PPE) needs in healthcare settings for the care of patients with suspected or confirmed 2019-nCoV. ECDC: Stockholm; 2020. https://www. ecdc.europa.eu/sites/default/files/documents/novel-coronavirus-personalprotective-equipment-needs-healthcare-settings.pdf

54. https://gis.gov.pl/wp-content/uploads/2020/04/rękawiczki.png

55. https://www.cdc.gov/coronavirus/2019-ncov/hcp/ppe-strategy/ventilators.htm

56. https://www.cdc.gov/coronavirus/2019-ncov/hcp/respirators-strategy/index.html

57. https://www.cdc.gov/coronavirus/2019-ncov/hcp/ppe-strategy/face-masks.html

58. https://www.cdc.gov/coronavirus/2019-ncov/hcp/ppe-strategy/isolation-gowns.html

59. https://www.cdc.gov/coronavirus/2019-ncov/hcp/ppe-strategy/eye-protection.html

60. https://www.ecdc.europa.eu/sites/default/files/documents/Cloth-face-masksin-case-shortage-surgical-masks-respirators2020-03-26.pdf

61. Liang T. (red.): COVID-19 Zapobieganie i leczenie; tłumaczenie polskie, wer-

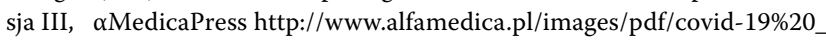
pl_2020_03_24.pdf

62. European Centre for Disease Prevention and Control (ECDC). Safe use of personal protective equipment in the treatment of infectious diseases of high consequence 2014 [cited 202025 February]. Stockholm: ECDC; 2020.

63. Operational considerations for case management of COVID-19 in health facility and community. WHO. 19 March 2020.

64. Puliatti S. et al.: COVID-19 and Urology: A Comprehensive Review of the Literature

65. Chłosta P., Drewa T., Słojewski M., Lipiński M, Kołodziej A. et al.: Współpraca: Mikołaj Przydacz Stanowisko Polskiego Towarzystwa Urologicznego wobec pandemii SARS-CoV-2.

66. Brindley P.G., Cardinal P.: Optimizing Crisis Resource Management to Improve Patient Safety and Team Performance. Royal College of Physicians and Surgeons of Canada. 1st. Edition May 15th, 2017 ISBN: 978-1-926588-40-7.

67. Liew M.F., Siow W.T., Yau Y.W. et al.: Safe patient transport for COVID-19. Crit Care 24, 94 (2020). https://doi.org/10.1186/s13054-020-2828-4.

68. Gu J., Han B., Wang J.: COVID-19: Gastrointestinal Manifestations and Potential Fecal-Oral Transmission [published online ahead of print, 2020 Mar 3]. Gastroenterology. 2020;S0016-5085(20)30281-X. doi:10.1053/j.gastro.2020.02.054.
69. Guo Y.R., Cao Q.D., Hong Z.S. et al.: The origin, transmission and clinical therapies on coronavirus disease 2019 (COVID-19) outbreak - an update on the status. Mil Med Res., 2020; 7(1): 11. Published 2020 Mar 13. doi:10.1186/ s40779-020-00240-0.

70. Morris S.N., Nickles Fader A., Magdy P., Milad M.P. et al.: Understanding the "Scope" of the Problem: Why Laparoscopy is Considered Safe During the COVID-19 Pandemic. The Journal of Minimally Invasive Gynecology (2020), doi: https://doi.org/10.1016/j.jmig.2020.04.002.

71. Brücher B.L.D.M., Nigri G., Tinelli A., Lapeña J.F.F. Jr. et al.: COVID-19: Pandemic surgery guidance. 4open, 2020; 3: 1 .

72. Wölfel R., Corman V.M., Guggemos W. et al.: Virological assessment of hospitalized patients with COVID-2019. Nature; 2020 Apr 1. doi: 10.1038/s41586020-2196-x. [Epub ahead of print].

73. Di Saverio S., Pata F., Gallo G. Et al.: Coronavirus pandemic and Colorectal surgery: practical advice based on the Italian experience. Colorectal Dis., 2020; Mar 31. doi: 10.1111/codi.15056. [Epub ahead of print].

74. Mintz Y., Arezzo A., Boni L., Chand M., Brodie R. et al.: A Low Cost, Safe and Effective Method for Smoke Evacuation in Laparoscopic Surgery for Suspected Coronavirus Patients. Annals of Surgery, 2020. https://journals.lww.com/ annalsofsurgery/Documents/A\%20Low\%20Cost,\%20Safe\%20and\%20Effective\%20Method\%20for\%20Smoke\%20Evacuation\%20in\%20Laparoscopic\%20 Surgery\%20for\%20Suspected\%20Coronavirus\%20Patients.pdf

75. Coccolini F., Catena F., Pisano M. et al.: Open versus laparoscopic cholecystectomy in acute cholecystitis. Systematic review and meta-analysis. Int J Surg., 2015; 18: 196. Epub 2015 May 6.

76. https://www.rcseng.ac.uk/coronavirus/joint-guidance-for-surgeons-v2/

77. https://www.sages.org/recommendations-surgical-response-covid-19/

78. https://eaes.eu/eaes-and-sages-recommendations-regarding-surgical-responseto-covid-19-crisis

79. https://eaes.eu/recomendaciones-de-la-asociacion-espanola-de-cirujanosin-spanish/1-recomendations-for-perioperative-managment-during-thepandemic-covid19-v-2/

80. Barazzoni R.: Espen expert statements and practical guidance for nutritional management of individuals with sars-cov-2 infection. Clin Nutr, 2020. https:// doi.org/10.1016/j.clnu.2020.03.022

81. Guidance on COVID-19v2.0, 23.03.2020 Use of PPE to support Infection Prevention and Control Practice when performing aerosol generating procedu res on CONFIRMED or CLINICALLY SUSPECTED COVID-19 CASES in a PANDEMIC SITUATION, https://www.hpsc.ie

82. Alhazzani W. et al.: Surviving Sepsis Campaign: Guidelines on the Management of Critically Ill Adults with Coronavirus Disease 2019 (COVID-19). Intensive Care Med., 2020; Mar 28. doi: 10.1007/s00134-020-06022-5.

83. European Medicines Agency. EMA gives advice on the use of non-steroidal anti-inflammatories for COVID-19. 2020. https://www.ema.europa.eu/en/ news/ema-gives-advice-use-non-steroidal-anti-inflammatories-covid-19 


Liczba słów: $8000 \quad$ Liczba stron: $12 \quad$ Tabele: $4 \quad$ Ryciny: $1 \quad$ Piśmiennictwo: 83

DOI: $\quad 10.5604 / 01.3001 .0014 .1039$

Table of content: https://ppch.pl/issue/12756

Copyright: Copyright @ 2020 Fundacja Polski Przegląd Chirurgiczny. Published by Index Copernicus Sp. z o. o. All rights reserved.

Competing interests: The authors declare that they have no competing interests.

The content of the journal "Polish Journal of Surgery" is circulated on the basis of the Open Access which means free and limitless access to scientific data.

(c) (1) (2) This material is available under the Creative Commons - Attribution 4.0 GB. The full terms of this license are available on: C.

Corresponding author: Prof. Kryspin Mitura MD PhD; University of Natural Sciences and Humanities in Siedlce, Faculty of Medical Sciences and Health Sciences, Poland; Department of General Surgery, Independent Municipal Hospital of the Public Health Care Center in Siedlce, Poland; Phone: +48 602809 035; E-mail: chirurgia.siedlce@gmail.com

Cite this article as: Mitura K., Mysliwiec P., Rogula W., Solecki M., Furtak J.P., Kazanowski M., Klek S., Nowakowski M., Pedziwiatr M., Zawadzki M., Wallner G., Sobocki J.: Guidelines for the management of surgical departments in non-uniform hospitals during the COVID-19 pandemic; Pol Przegl Chir 2020: 92 (2): $42-53$ 